\title{
Variations in trace metal and aflatoxin content during processing of High Quality Cassava Flour (HQCF)
}

\author{
Hayford Ofori", Paa Toah Akonor and Nanam Tay Dziedzoave
}

\begin{abstract}
Background: High Quality Cassava Flour (HQCF) has gained popularity in most parts of West Africa because of its versatility in many industries. However, due to the processing techniques used HQCF may contain trace metals and aflatoxins. Imperatively, the safety of HQCF was assessed when the levels of trace metal and aflatoxin contaminants was determined at the various unit operation during HQCF production.
\end{abstract}

Results: Concentrations of essential trace metals, $\mathrm{Cu}$, Fe and Zn ranged from $0.79 \pm 0.09$ to1.85 $\pm 0.26,10.91 \pm 0.44$ to $16.64 \pm 0.35$ and $3.92 \pm 0.03$ to $10.79 \pm 0.16 \mathrm{mg} / \mathrm{kg}$ respectively. Toxic trace metals; As and Pb were not detected in any of the samples analysed. The maximum concentration of $\mathrm{Hg}$ determined was $<0.1 \mathrm{mg} / \mathrm{kg}$. Aflatoxin $B_{1}, B_{2}, G_{1}$ and $\mathrm{G}_{2}$ were not detected in any of the HQCF samples analysed.

Conclusion: The concentrations of $\mathrm{As}, \mathrm{Cu}, \mathrm{Fe}, \mathrm{Hg}, \mathrm{Pb}$, and $\mathrm{Zn}$ in HQCF were below the limit set by WHO whilst aflatoxin $B_{1}, B_{2}, G_{1}$ and $G_{2}$ was not detected in $H Q C F$ and therefore pose no public health threat.

Keywords: Cassava, Contaminants, Trace metal, Aflatoxins, WHO

\section{Background}

Cassava (Manihot esculenta) is one of the most important root tubers in Africa and serves as a food security crop for millions of people on the continent. According to a report by the Ministry of Food and Agriculture, Ghana (MoFA 2013) cassava ranks first among root crops in Ghana, with over 14 million MT of the crop produced in the year 2012. Customarily, cassava is largely consumed locally and does not return considerable amounts of foreign exchange. About $50 \%$ of the roots are consumed fresh at household level, whilst the remainder is processed into other forms such as cassava chips and flour. Only $1 \%$ of the cassava produced is used for industrial purposes.

In recent times attempts have been made to add more value to cassava and also make it more useful as a raw material for industrial applications. One of the approaches has been to process the roots into unfermented flour for domestic and industrial uses. This flour, also

\footnotetext{
* Correspondence: oforihayford@yahoo.com

Council for Scientific and Industrial Research-Food Research Institute, P. O. Box M 2O, Accra, Ghana
}

known as High Quality Cassava Flour (HQCF) is useful for bakery products, production of glucose syrup and starch as well as use as a glue extender for the plywood industry. HQCF can also serve as a source of starch for the textile industry.

Heavy metal and aflatoxin contaminants in foods have become a matter of public health concern in recent times (Aradhna et al., 2009). Heavy metals such as copper $(\mathrm{Cu})$, iron $(\mathrm{Fe})$, and zinc $(\mathrm{Zn})$ are considered as essential elements because of their role as co-factors in metabolic and biosynthetic processes. Lead $(\mathrm{Pb})$, arsenic (As), and mercury $(\mathrm{Hg})$ are non-essential, for they have no known beneficiary roles and are toxic above certain levels. The essential metals may produce toxic effect at high concentrations (Celik \& Oehlenschlager, 2007; Tuzen, 2009). Heavy metals accumulate in human organs such as liver, kidney, bone and causes severe health disorders. For example $\mathrm{Pb}$ can cause renal masses, affect cognitive development and may lead to adult cardiovascular disease (Bandara et al., 2008). Mercury is considered by WHO as one of the top ten chemicals or groups of chemicals of major public health concern. Mercury may have toxic effects on the nervous, digestive

\section{Springer}


and immune systems, and on lungs, kidneys, skins and eyes (WHO, 2003). For fetuses, infants and children, the primary health effect of $\mathrm{Hg}$ is impaired neurological development. Arsenic is also considered as toxic. Ingestion of As leads to gastrointestinal symptoms, and disturbances of cardiovascular and nervous systems functions. Long-term exposure to As is casually related to increased risk of cancer (Xiong et al., 2013). Aflatoxins are known to be carcinogenic. Aflatoxin contamination in food is caused by the presence of Aspergillus flavus, Aspergillus nomius and Aspergillus parasiticus (Essono et al., 2009). These organisms usually contaminate the food product and synthesize the toxins as metabolites in the presence of high levels of carbohydrates and low levels of protein (Essono et al., 2009).

In the present study, variations in trace metal and aflatoxin content of cassava during processing into $\mathrm{HQCF}$ was assessed by determining the levels of $\mathrm{As}, \mathrm{Cu}, \mathrm{Fe}$, $\mathrm{Hg}, \mathrm{Pb}, \mathrm{Zn}$, aflatoxins $\mathrm{B}_{1}, \mathrm{~B}_{2}, \mathrm{G}_{1}$ and $\mathrm{G}_{2}$ in raw cassava, grated cassava dough, dried grits, dried cassava chips, and HQCF. The levels of the contaminants were compared to $\mathrm{WHO}$ a specifications to ascertain the risk posed to the health of the general public.

\section{Methods}

\section{Sample preparation}

Mature cassava aged ten months was bought from Bawjiase in the Central Region of Ghana and transported on the same day to Root and Tuber Products Development Unit of the CSIR-Food Research Institute (FRI) for processing into High Quality Cassava Flour (HQCF). The cassava variety processed was Esam bankye. Samples were taken from each unit operation along the processing line for trace metal and aflatoxin analyses. Samples analysed include raw cassava, grated cassava dough, dried grits, dried chips, high quality cassava flour from solar dried chips (SDC-HQCF), high quality cassava flour from solar dried grits (SDG-HQCF), high quality cassava flour from mechanically dried chips (MDC-HQCF) and high quality cassava flour from mechanically dried grits (MDGHQCF).

\section{Processing cassava roots into HQCF HQCF produced by grating}

Cassava root was processed into HQCF using the method described by Dziedzoave et al., 2006. The roots were washed with potable water and hand-peeled with stainless steel knives and washed twice in potable water before further processing. Peeled cassava roots were then grated in a motorized grater. The grated mash was immediately loaded into polypropylene woven sacks and dewatered in a manual single screw press. The pressed cake was disintegrated manually and spread thinly on trays for drying in either a solar tent dryer or a mechanical dryer. Solar drying took place over a period of $14 \mathrm{~h}$ during which the thinly spread granules were turned several times. Mechanical drying also took place for $8 \mathrm{~h}$ at $60{ }^{\circ} \mathrm{C}$ in a diesel-operated walk-in cabinet dryer. The dried granules were milled in a hammer mill and sieved $(250 \mu \mathrm{m})$ to obtain smooth and free-flowing flour.

\section{HQCF produced by slicing/chi pping}

Cassava roots were washed and peeled as described in the previous section. Peeled cassava roots were quickly chipped ( $<5 \mathrm{~mm}$ thickness) in a motorized slicer. The freshly chipped roots were immediately spread thinly on drying trays and dried either in a solar tent dryer or a mechanical dryer. Solar drying took place over a period of $14 \mathrm{~h}$ during which the thinly spread chips were turned several times. Mechanical drying also took place for $8 \mathrm{~h}$ at $60{ }^{\circ} \mathrm{C}$ in a diesel-operated walk-in cabinet dryer. The dried chips were milled in a disc attrition mill and sieved $(250 \mu \mathrm{m})$ to obtain a smooth and free-flowing flour.

\section{Chemical analyses \\ Aflatoxins determination}

The extraction procedure used for the determination of aflatoxins was by the Stroka and Anklam (1991). A test portion $(50 \mathrm{~g})$ was extracted with $200 \mathrm{ml}$ methanol/ water solvent solution containing $5 \mathrm{~g}$ of sodium chloride. The sample extract was filtered, diluted with phosphate buffered saline to a specified solvent concentration and applied to the immunoaffinity column (R-Biopharm Rhone Ltd. Easi-Extract Aflatoxin) containing antibodies specific for aflatoxins $B_{1}, B_{2}, G_{1}$ and $G_{2}$. Aflatoxins were eluted from the immunoaffinity columns with neat methanol. The Aflatoxin level was quantified by reversephase high performance liquid chromatography (RP-HPLC) with post column derivatisation (PCD) involving bromination. The PCD was achieved with pyrimidinum hydrobromide perbromide ( $\mathrm{PBPB}$ ) followed by fluorescence detection. HPLC system used for analyses was from Waters Associates (Milford, MA, USA) and included Waters 1525 Binary HPLC pump, Waters 2707 Autosampler, Waters Model 1500 Column Heater, Waters 2475 Multi $\lambda$ Fluorescence Detector and Breeze 2 software. Separation of the aflatoxin was carried out on a Spherisorb S5 ODS-1 column of dimensions $25 \times 4.6 \mathrm{~mm}$ packed with $5 \mu \mathrm{m}$ particles (phase separation In., Norwalk, USA) maintained at $35^{\circ} \mathrm{C}$. The HPLC mobile-phase flow rate was $10 \mathrm{ml} / \mathrm{min}$ and post column bromine derivatisation of Aflatoxin $B_{1}$, and $G_{1}$ was achieved by PBPB dissolved in $500 \mathrm{ml}$ of demineralised water pumped at a flow rate of $1.0 \mathrm{ml} / \mathrm{min}$ using Elder precision metering pump (Elder laboratories Inc., Sam Carlos, USA). The excitation and emission wave length used were $360 \mathrm{~nm}$ and $440 \mathrm{~nm}$ respectively. The Aflatoxin were identified by means of their retention 
Table 1 Variations in concentration of trace metal in mg/kg wet weight of raw cassava, grated dough, dried grits, and HQCF

\begin{tabular}{lllllll}
\hline Sample & $\mathrm{Cu}$ & $\mathrm{Fe}$ & $\mathrm{As}$ & $\mathrm{Hg}$ & $\mathrm{Pb}$ & $\mathrm{Zn}$ \\
\hline Raw cassava & $2.05 \pm 0.26^{\mathrm{d}}$ & $14.59 \pm 0.23^{\mathrm{bc}}$ & $\mathrm{ND}$ & $<0.01^{\mathrm{a}}$ & $\mathrm{ND}$ & $6.49 \pm 0.06^{\mathrm{bc}}$ \\
Grated dough & $1.57 \pm 0.26^{\mathrm{bcd}}$ & $16.64 \pm 0.35^{\mathrm{d}}$ & $\mathrm{ND}$ & $<0.01^{\mathrm{a}}$ & $\mathrm{ND}$ & $9.02 \pm 0.58^{\mathrm{d}}$ \\
Dried grits & $1.39 \pm 0.15^{\mathrm{bc}}$ & $13.16 \pm 0.05^{\mathrm{b}}$ & $\mathrm{ND}$ & $<0.01^{\mathrm{a}}$ & $\mathrm{ND}$ & $5.05 \pm 0.27^{\mathrm{ab}}$ \\
SDG-HQCF & $0.79 \pm 0.09^{\mathrm{a}}$ & $13.30 \pm 0.71^{\mathrm{bc}}$ & $\mathrm{ND}$ & $<0.01^{\mathrm{a}}$ & $\mathrm{ND}$ & $5.79 \pm 0.16^{\mathrm{b}}$ \\
MDG-HQCF & $1.02 \pm 0.08^{\mathrm{ab}}$ & $10.91 \pm 0.44^{\mathrm{a}}$ & $\mathrm{ND}$ & $<0.01^{\mathrm{a}}$ & $\mathrm{ND}$ & $3.92 \pm 0.03^{\mathrm{a}}$ \\
\hline
\end{tabular}

Results are presented as means \pm standard deviation. Superscripts to figures in the same column implies significant or insignificant differences at $\mathrm{p} \leq 0.05$ (ANOVA, Duncan test). *ND means not detected. Limit of detection for $\mathrm{As}=0.02 \mathrm{mg} / \mathrm{kg}$, and $\mathrm{Pb}=0.1 \mathrm{mg} / \mathrm{kg}$

times, and quantification was performed by comparing the peak areas of the samples to those of the standards prepared from pure aflatoxins standardwere (obtained from R. Biopharm) solutions under identified conditions.

\section{Heavy metal determination}

The dry ashing method was used for Atomic Absorption Spectrometry (AAS) analysis (AOAC 2005). All glassware was washed with $1 \%$ nitric acid followed by demineralised water. Three grams of each sample was weighed into a platinum crucible. The crucible and the test portion was placed in the Muffle furnace at a temperature $550{ }^{\circ} \mathrm{C}$ for $8 \mathrm{~h}$. The crucible with ash was put in a desiccator to cool. Five (5) $\mathrm{mL}$ of nitric acid of mass fraction not less than $65 \%$, having a density of approximately $\rho\left(\mathrm{HNO}_{3}\right)=1400 \mathrm{mg} \cdot \mathrm{mL}^{-1}$ was added, ensuring that all the ash came into contact with the acid and the resultant solution heated on hot plate until the ash dissolved. Ten (10) $\mathrm{mL}$ of $0.1 \mathrm{~mol} . \mathrm{L}^{-1}$ nitric acid was added and filtered into $50 \mathrm{ml}$ volumetric flask. The resultant solution was topped up to the mark with 0.1 mol. $\mathrm{L}^{-1}$ nitric acid. Blank solution was treated the same way as the sample. Buck Scientific 210VGP Flame Atomic Absorption Spectrophotometer (Buck Scientific, Inc. East Norwalk, USA) was used to read the absorbance values at appropriate wavelength of the interested metal in the sample solution. Cathode lamps used were As (wavelength $193.7 \mathrm{~nm}$, lamp current $4.0 \mathrm{~mA}$ ), $\mathrm{Cu}$ (wavelength $324.8 \mathrm{~nm}$, lamp current $1.5 \mathrm{~mA}$ ), Fe (wavelength $248.3 \mathrm{~nm}$, lamp current $7.0 \mathrm{~mA}$ ), $\mathrm{Hg}$ (wave length $253.7 \mathrm{~nm}$, lamp current $0.7 \mathrm{~mA}$ ), $\mathrm{Pb}$ (wavelength $217.0 \mathrm{~nm}$, lamp current $3.0 \mathrm{~mA}$ ) and $\mathrm{Zn}$ (wavelength $213.9 \mathrm{~nm}$, lamp current $2.0 \mathrm{~mA}$ ). The metal content of the samples were derived from calibration curves made up of a minimum of three standards.

\section{Quality control of results}

Samples were handled carefully to avoid contamination as part of measure to ensure reliability of results. The recovery test of the total analytical procedures was also carried out for the metals analysed in the selected samples by spiking analysed samples with aliquots of metal standards and then reanalysed the samples. Acceptable recoveries of $95 \pm 1,97 \pm 1,95 \pm 1,94 \pm 1,95 \pm 1,96 \pm 1 \%$ were obtained for $\mathrm{As}, \mathrm{Cu}, \mathrm{Fe}, \mathrm{Hg}, \mathrm{Pb}$ and $\mathrm{Zn}$ respectively.

\section{Data analysis}

The standard deviations on mean values of duplicate samples were analysed using Statistical Package for Social Scientist (SPSS, 2005), version 16. ANOVA, Duncan test was used to compare the means.

\section{Results and discussion}

\section{Trace metal analyses}

The concentration of $\mathrm{As}, \mathrm{Cu}, \mathrm{Fe}, \mathrm{Hg}, \mathrm{Pb}$, and $\mathrm{Zn}$ in raw cassava, grated cassava dough, grits, dried chips, SDCHQCF, SDG-HQCF, MDC-HQCF and MDG-HQCF is shown in Tables 1 and 2. Lead is toxic even at trace levels (Dobaradaren et al. 2010). Lead was not detected in any of the samples analysed and therefore poses no public health threat. Copper is an essential constituent of some metalloenzymes and is required for haemoglobin synthesis and in the catalysis of metabolic growth (Silvestre et al., 2000). The maximum and minimum $\mathrm{Cu}$ concentration determined was $1.85 \pm 0.26$ and $0.79 \pm 0.09 \mathrm{mg} / \mathrm{kg}$ respectively which are far below the limit of $40 \mathrm{mg} / \mathrm{kg}$ limit set by

Table 2 Variations in concentration of trace metal in $\mathrm{mg} / \mathrm{kg}$ wet weight of raw cassava, dried chips, and HQCF

\begin{tabular}{lllllll}
\hline Sample & $\mathrm{Cu}$ & $\mathrm{Fe}$ & $\mathrm{As}$ & $\mathrm{Hg}$ & $\mathrm{Pb}$ & $\mathrm{Zn}$ \\
\hline Raw cassava & $2.05 \pm 0.18^{\mathrm{d}}$ & $14.59 \pm 0.23^{\mathrm{ab}}$ & $\mathrm{ND}^{*}$ & $<0.01^{\mathrm{a}}$ & $\mathrm{ND}^{*}$ & $6^{\mathrm{a}}$ \\
Dried chips & $1.74 \pm 0.26^{\mathrm{cd}}$ & $16.37 \pm 0.33^{\mathrm{c}}$ & $\mathrm{ND}$ & $<0.06^{\mathrm{c}}$ \\
SDC-HQCF & $1.36 \pm 0.11^{\mathrm{ac}}$ & $14.75 \pm 0.65^{\mathrm{a}}$ & $\mathrm{ND}$ & $<0.01^{\mathrm{a}}$ & $\mathrm{ND}$ & $7.44 \pm 0.06^{\mathrm{c}}$ \\
MDC-HQCF & $1.15 \pm 0.21^{\mathrm{a}}$ & $11.32 \pm 0.01^{\mathrm{a}}$ & $\mathrm{ND}$ & $<0.01^{\mathrm{a}}$ & $\mathrm{ND}$ & $9.28 \pm 0.12^{\mathrm{a}}$ \\
\hline
\end{tabular}

*ND means not detected. Limit of detection for $\mathrm{As}=0.02 \mathrm{mg} / \mathrm{kg}$ and $\mathrm{Pb}=0.1 \mathrm{mg} / \mathrm{kg}$

Results are presented as means \pm standard deviation. Superscripts to figures in the same column implies significant or insignificant differences at $\mathrm{p} \leq 0.05$ (ANOVA, Duncan test) 
WHO (WHO, 1982). Statistically, there was no significant difference between the levels of $\mathrm{Cu}$ determined in the solar dried grated - high quality cassava flour (SDG-HQCF) and mechanically dried grated - high quality cassava flour (MDG-HQCF) at $\mathrm{p} \leq 0.05$. The difference in $\mathrm{Cu}$ concentration between solar dried chips-high quality cassava flour (SDC-HQCF) and mechanically dried - high quality cassava flour (MDC-HQCF) was also statistically not significant. According to Senesse et al., 2004; excess intake of $\mathrm{Fe}$ is associated with an increased risk of colorectal cancer. The concentration of Fe determined ranged from $10.91 \pm 0.44$ to $16.64 \pm 0.35 \mathrm{mg} / \mathrm{kg}$ in which the maximum concentration slightly exceed the $15 \mathrm{mg} / \mathrm{kg}$ limit set by WHO (WHO, 1982). However, the maximum and minimum Fe concentrations determined in the HQCF samples analysed was $14.75 \pm 0.65$ and $10.91 \pm 0.44 \mathrm{mg} / \mathrm{kg}$ respectively and are below the $15 \mathrm{mg} / \mathrm{kg}$ limit set WHO. Impairment related to $\mathrm{Hg}$ toxicity includes peripheral vision, disturbances in sensations, muscle weakness and lack of movement coordination (Xiong et al., 2013). The highest concentration of $\mathrm{Hg}$ determined was $<0.01 \mathrm{mk} / \mathrm{kg}$. WHO has recommended a Provisional Tolerable Weekly Intake (PTWI) of $\mathrm{Hg}$ as $1.6 \mu \mathrm{g} / \mathrm{kg}$ body weight (WHO, 2003). Mercury level in samples analysed do not pose public health concern. Zinc constitutes about $33 \mathrm{ppm}$ of adult body weight and is essential as a constituent of many enzymes involved in a number of physiological functions, such as protein synthesis and energy metabolism (Ma and Betts, 2000). The concentration of $\mathrm{Zn}$ determined ranged from $3.92 \pm 0.03$ to $10.79 \pm 0.16 \mathrm{mg} / \mathrm{kg}$ which is far below the limit of $60 \mathrm{mg} / \mathrm{kg}$ set by WHO (WHO, 1982). Statistically, there was significant difference between $\mathrm{Zn}$ concentration determined in HQCF produced from sliced cassava and HQCF produced from grated cassava at $\mathrm{p} \leq 0.05$.

\section{Aflatoxin analyses}

The recovery of the analytical method was 90.50, 76.56, 95.58, $91.76 \%$ for $B_{1}, B_{2}, G_{1}$ and $G_{2}$ respectively with linearity $\mathrm{R}^{2}=0.999 \%$. Aflatoxin was not detected in any of the samples analysed which is in conformity with the findings by Gnonlonfin et al., 2012 which stated the absence of aflatoxin in cassava chips from Benin, West Africa. Limit of detection for aflatoxin $B_{1}$ and $B_{2}=0.15 \mu / \mathrm{kg}$ and aflatoxin $G_{1}$ and $\mathrm{G}_{2}=0.13 \mu / \mathrm{kg}$. According to Essono et al., 2009; $75 \%$ of cassava chips analysed for aflatoxin in Cameroon, West Africa did not contain aflatoxin at detectable levels whereas $25 \%$ did depending on processing practices, storage facilities, and storage duration. Samples analysed presently did not contain aflatoxins in detectable levels which is an indication that cassava chips and HQCF samples were processed under good processing practices.

\section{Conclusion}

The maximum and minimum $\mathrm{Cu}$ concentration determined was $2.05 \pm 0.26$ and $0.79 \pm 0.09 \mathrm{mg} / \mathrm{kg}$ respectively whiles that of $\mathrm{Fe}$ and $\mathrm{Zn}$ was $16.64 \pm 0.35$ and $10.91 \pm 0.44$; $10.79 \pm 0.16$ and $3.92 \pm 0.03 \mathrm{mg} / \mathrm{kg}$ respectively. As, $\mathrm{Hg}$ and $\mathrm{Pb}$ concentrations determined were all below the WHO set limit and therefore pose no public health threat. Aflatoxins $B_{1}, B_{2}, G_{1}$ and $G_{2}$ were not detected in any of the samples analysed.

\section{Competing interests}

All authors declare that there is no competing interest where so ever.

\section{Authors' contribution}

The work was done in collaboration between all authors. Author $\mathrm{HO}$ conducted the literature search and wrote the first draft of the manuscript. Authors $\mathrm{HO}$,

PTA and NTD read and approved the final draft of the manuscript.

\section{Acknowledgement}

This is an output from the Ghana component of cassava G-market project, funded by the European Union (EU). The views expressed are not necessarily those of the EU.

Received: 3 November 2015 Accepted: 27 December 2015

Published online: 04 January 2016

\section{References}

AOAC. Official methods of analysis of AOAC International. 18th ed. Gaithersburg, Maryland, USA: AOAC International; 2005.

Aradhna G, Devendra KR, Ravi SP, Bechan S. Analysis of some heavy metals in the riverine water, sediments, and fish from Ganges at Allhabad. Environ Monit Assess. 2009;157:449-58.

Bandara JMRS, Senevirathna DMAN, Dasanayake DMRSB, Herath V, Bandara JMRP Abeysekara T, et al. Chronic renal failure among farm families in cascade irrigation systems in Sri Lanka associated with elevated dietary cadmium levels in rice and freshwater fish (Tilapia). Environ Geochem Health. 2008:30:465-78.

Celik U, Oehlenschlager J. High of cadmium, lead, zinc and copper in popular fishery products sold in Turkish supermarkets. Food Control. 2007;18(3):258-61.

Dobaradaren S, Kaddafi K, Nazmara S, Ghaedi H. Heavy metals (Cd, Cu, Ni and Pb) content in fish species of Persian Gulf in Bushehr Port. Iran A J Biotech. 2010:32:6191-3

Dziedzoave NT, Abass AB, Amoa-Awua WK, Sablah M. Quality management manual for production of high quality cassava flour. International institute of tropical agriculture. Nigeria: Ibadan; 2006.

Essono G, Ayodele M, Akoa A, Foko J, Filtenborg O, Olembo S. Aflatoxin-producing Aspergillus spp. and aflatoxin levels in stored cassava chips as affected by processing practices. Food Control. 2009;20:648-54.

Gnonlonfin GJB, Adjovi CSY, Katerere DR, Shephard GS, Sanni A, Brimer L. Mycoflora and absence of aflatoxin contamination of commercialized cassava chips in Benin, West Africa. Food Control. 2012;23:333-7.

Ma J, Betts NM. Zinc and Copper intakes and their major food sources for older adults in the 1994-96 continuing survey of food intakes by individual 9CSF-II). J Nutr. 2000;130:2838-43.

MoFA. Agriculture in Ghana, Facts and Figures, 2012. Statistical Research and Information Directorate (SRID). Ghana: Ministry of Food and Agriculture; 2013.

Sennese P, Meance S, Cottet V, Faivre J, Boutron-Ruault MC. High dietary iron and copper and risk of colorectal cancer: a case-control study in Burgundy. France Nutr cancer. 2004;46:66-71.

Silvestre MD, Lagarda MJ, Farra R, Martineze-Costa C, Brines J. Copper, iron and zinc determination in human milk using FAAS with microwave digestion. Food Chem. 2000;68:95-9.

SPSS 16 for Windows (2005). SPSS 16 for windows. Chicago.Illinois,USA. Stroka J, Anklam E. Quantitative analysis for aflatoxins. JAOAC. 1991;74:81-4.

Tuzen M. Toxic and essential trace elemental contents in fish species from Black Sea, Turkey. Food Chem Toxicol. 2009;47(8):1785-90.

World Health Organisation (WHO). Evaluation of certain food additives and contaminants (twenty-six report of the joint FAO/WHO expert committee on food additives). WHO technical report series, No.683 Geneva. 1982. 
World Health Organisation (WHO). Evaluation of certain food additives and contaminants (sixty-first report of the joint FAO/WHO expert committee on food additives). WHO technical report series, No. JECFA/61/SC, Rome. 2003. Xiong C, Zhang Y, Xu X, Lu Y, Ouyang B, Ye Z, et al. Lotus roots accumulate heavy metals independently from soil in main production regions of China. Scientia Horticulturea. 2013;164:295-302.

\section{Submit your manuscript to a SpringerOpen ${ }^{\circ}$ journal and benefit from:}

- Convenient online submission

- Rigorous peer review

- Immediate publication on acceptance

- Open access: articles freely available online

- High visibility within the field

- Retaining the copyright to your article

Submit your next manuscript at $>$ springeropen.com 